\author{
Marcin KRÓLIKOWSKI ${ }^{1}$ \\ Justyna MAZURKIEWICZ ${ }^{2}$ \\ Anna WACHOWICZ ${ }^{3}$
}

\title{
POJAZDY HYBRYDOWE A SYSTEMY FOTOWOLTAICZNE - MOŻLIWOŚCI WYKORZYSTANIA (PROJEKT OZI)
}

\begin{abstract}
Artykuł podejmuje tematykę pojazdów hybrydowych wykorzystujących systemy fotowoltaiczne jako jedno ze źródeł energii elektrycznej niezbędnej do pracy tego typu urządzeń. Opisano podstawowe rozwiązania stosowane w/w pojazdach oraz zasadę działania poszczególnych podzespołów. Głównym, poruszanym tematem jest projekt pojazdu hybrydowego OZI który został wykonany przez studentów Akademii Górniczo - Hutniczej w Krakowie. Przedstawiono metodykę obliczeniową wykorzystaną w celu doboru elementów pojazdu. Obliczono wielkość oporów toczenia, oporów powietrza oraz moc silnika niezbędną do pokonania wymienionych oporów. Ponadto dobrano akumulatory o niezbędnej pojemności oraz panele fotowoltaiczne o odpowiedniej mocy, pozwalającej na poprawne działanie sytemu. Tekst artykułu przedstawia najczęściej stosowane rozwiązanie konstrukcyjne w pojazdach hybrydowych $\mathrm{z}$ wykorzystaniem systemów fotowoltaicznych oraz rozwiązanie zastosowane w projekcie OZI. Przeprowadzono badania nad pojazdem OZI które obejmowały wartości mocy prądu elektrycznego przepływającego pomiędzy akumulatorami a kontrolerem ładowania akumulatorów, kontrolerem ładowania akumulatorów a silnikiem. Badania prowadzono bez udziału fotoprądu oraz podczas generacji prądu elektrycznego powstającego w wyniku efektu fotowoltaicznego. Do badań wykorzystano multimetry elektronicznie z których dokonywano odczytu pomiarów natężenia i napięcia prądu w interwale 15 sekund. Dodatkowo wyznaczono maksymalny czas ciągłej pracy pojazdu w celu oszacowania jego praktycznego wykorzystania. W celu oszacowania praktycznych korzyści oraz podania docelowej grupy użytkowników powołano się na wyniki badań organizacji Transport Statistics Great Britain z roku 2007.
\end{abstract}

Słowa kluczowe: energia słoneczna, opory toczenia, opory powietrza, transport

\footnotetext{
${ }^{1}$ Autor do korespondencji: Marcin Królikowski, Akademia Górniczo-Hutnicza w Krakowie, WGGiOŚ, al. A. Mickiewicza 30, 30-059 Kraków, 12 6172360, mkr@ agh.edu.pl.

2 Justyna Mazurkiewicz, Akademia Górniczo-Hutnicza w Krakowie, WGGiOŚ, al. A. Mickiewicza 30, 30-059 Kraków, 12 6172404, mazurkiewicz@geol.agh.edu.pl

3 Anna Wachowicz, Akademia Górniczo-Hutnicza w Krakowie, WGGiOŚ, al. A. Mickiewicza 30,30-059 Kraków, 12 6172360, amwachow@gmail.com
} 


\section{Wykaz skrótów:}

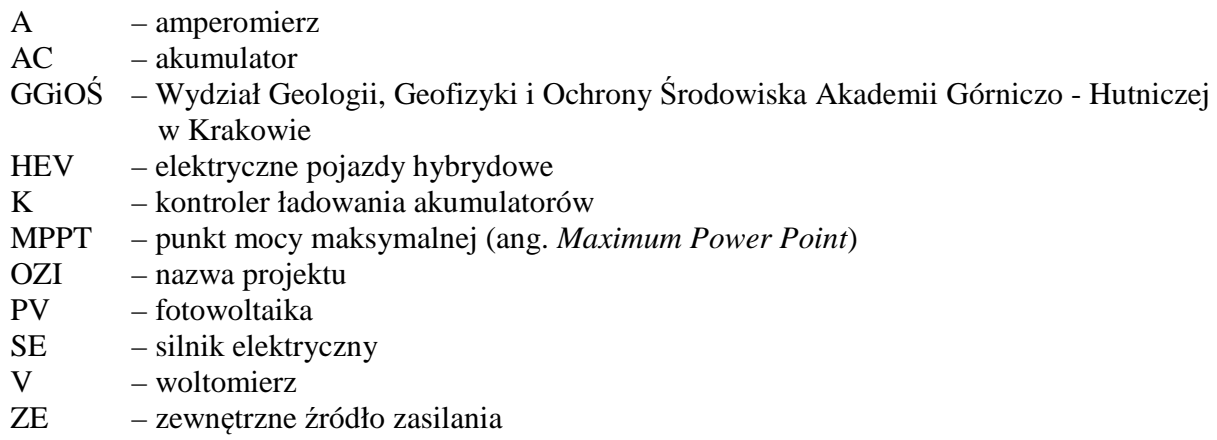

\section{Wprowadzenia}

Na przełomie ostatnich lat zauważalny jest znaczny wzrost zainteresowania elektrycznymi oraz hybrydowymi (HEV) pojazdami cywilnymi wykorzystującymi promieniowanie słoneczne jako jedno ze źródeł energii. Wielu naukowców z całego świata z powodzeniem testuje prototypy takich pojazdów.

Za wzrostem zainteresowania przemawia przede wszystkim wszechobecne oraz praktycznie niewyczerpywalne źródło energii jakim jest promieniowanie słońca. Mimo znacznych problemów technologicznych przy stosowaniu fotowoltaiki (PV) nie zauważa się spadku zainteresowania tą technologią wśród konstruktorów pojazdów elektrycznych. Systemy te znajdują zastosowanie w rozwiązywaniu istotnych problemów dotyczących redukcji emisji gazów cieplarnianych.

Wykorzystanie energii słońca do zasilania pojazdów elektrycznych znajduje również wielu sceptyków w środowisku naukowym oraz wśród inżynierów. Takie podejście podyktowane jest sprawnością (uzysk energetyczny) tych rozwiązań biorąc pod uwagę zapotrzebowanie na energię elektryczną w pojazdach $\mathrm{z}$ napędem elektrycznym.

Zgodnie z Transport Statistics Great Britain z roku 2007, znacząca ilość użytkowników miejskich pojazdów wykorzystuje osobisty transport samochodowy na małych odległościach i przejazdach nie dłuższych niż 20 minut [7]. Ponad to najczęściej stosowane rozwiązania w pojazdach (HEV) to konstrukcje jedno osobowe lub dwuosobowe [5]. Takie warunki podróżowania pozwalają na skuteczne zastosowanie instalacji PV.

Rozwiązania konstrukcyjne dla pojazdów konwencjonalnych nie znajdują bezpośredniego odzwierciedlenia $\mathrm{w}$ pojazdach hybrydowych $\mathrm{z}$ technologią PV. Dlatego podczas projektowania należy uwzględnić głównie takie parametry jak waga pojazdu, aerodynamika, strategia w zarządzaniu energią [3]. Uwzględnić należy również strategią pozyskiwania oraz gromadzenia energii produkowanej z PV[4]. 
Obecnie powstało wiele projektów pojazdów pozyskujących energię z PV między innymi w Japonii, Western Washington University, Queensland University oraz wiele innych [1][2]. Za przykłady posłużyć mogą pojazdy o nazwie „Promyk słońca”, „Manta GTX”, „Maize blaize”, „NED” oraz wiele innych [4]. Jednym z projektów stworzonych w Polsce jest projekt OZI. Projekt ten powstał na Wydziale GGiOŚ Akademii Górniczo-Hutniczej w Krakowie. Twórcami byli studenci zrzeszeni $\mathrm{w}$ kole naukowym odnawialnych źródeł energii GRZAŁA. Przedsięwzięcie to miało na celu stworzenie instrumentu badawczego pozwalającego studentom kierunku Inżynieria Środowiska na rozwijanie umiejętności praktycznych w systemach PV. Projekt OZI w niniejszym artykule został dogłębniej przestawiony jako przykład

\section{Model pojazdu solarno-hybrydowego}

Obecnie stosowanych jest kilka rozwiązań napędu w pojazdach hybrydowych wykorzystujących systemy PV. Najczęstsze rozwiązanie zbudowane jest $\mathrm{z}$ paneli fotowoltaicznych połączonych szeregowo lub szeregowo / równolegle (PV), systemu akumulatorów (AC), silnika elektrycznego (SE), dodatkowego źródła energii elektrycznej (ZE) oraz kontrolera (K).

$\mathrm{W}$ modelu pojazdu przedstawionego na rysunku $\mathrm{nr} 1$ silnik elektryczny oprócz elementu napędowego pełni funkcję generatora prądu elektrycznego. $\mathrm{W}$ trakcie hamowania pojazdu energia kinetyczna zamieniana jest na energię elektryczną, która po zmagazynowaniu w akumulatorze może zostać wykorzystana podczas przemieszczania się pojazdem. Działanie pozostałych elementów bazowych pojazdu opisano w punkcie 2.2. Tego typu rozwiązania stosowane są $\mathrm{w}$ pojazdach produkowanych seryjnie takich jak Toyota Prius oraz Honda Civic. Należy zauważyć, że PV w w/w pojazdach stosowany jest w celu zapewnienia energii elektrycznej wykorzystywanej do poprawnej pracy klimatyzacji oraz urządzeń pokładowych [6].

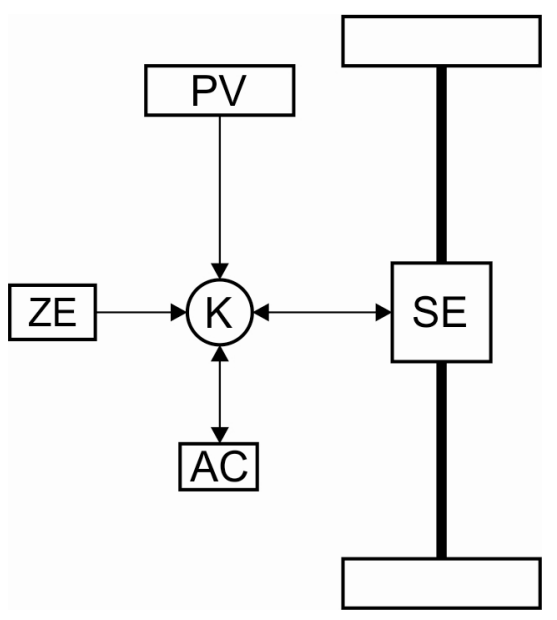

Rys. 1. Model pojazdu solarno-hybrydowego Fig. 1. Model of solar hybrid vehicle 


\section{Projekt OZI}

\subsection{Wprowadzenie}

Projekt OZI swe początki miał jako koncepcja pojazdu o napędzie hybrydowym która powstała podczas działalności koła naukowego Odnawialnych Źródeł Energii „GRZAŁA” na Wydziale GGiOŚ AGH w Krakowie. Głównymi założeniami projektu były:

- pojazd trójkołowy jednoosobowy,

- dwa źródła napędu (elektryczny, mechaniczny),

- dwa źródła energii (konwersja fotowoltaiczna, energia ludzkich mięśni),

- wykorzystanie podzespołów konstrukcyjnych dostępnych na rynku ogólnym.

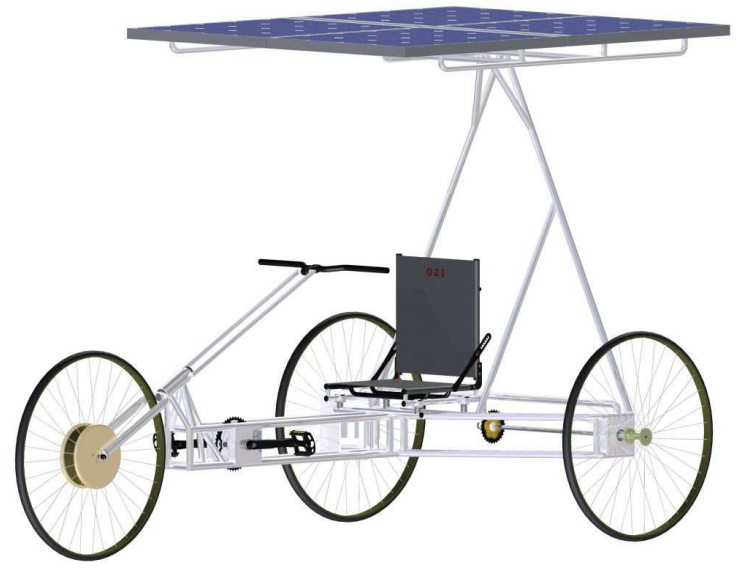

Rys. 2. Poglądowy model pojazdu OZI

Fig. 2. The illustrative model of the OZI vehicle

\subsection{Model projektu OZI}

Jako źródło energii elektrycznej wykorzystano zestaw 4 paneli fotowoltaicznych (PV), krzemowych, monokrystalicznych połączonych szeregowo o łącznym napięciu 48V, prądzie zwarcia 3,72A, łącznej mocy $240 \mathrm{~W}$ i sprawności $18 \%$. Panele zamontowano na pojeździe $\mathrm{w}$ formie dachu $\mathrm{z}$ możliwością regulacji nachylenia $w$ jednej płaszczyźnie. Energia uzyskana z konwersji fotoelektrycznej przekazywana jest do kontrolera ładowania akumulatorów (K). Następnie w zależności od potrzeb przekazywana jest przez kontroler do czterech akumulatorów żelowych (AC) połączonych szeregowo (każdy o napięciu $12 \mathrm{~V}$ oraz pojemności 17Ah) o łącznym napięciu $48 \mathrm{~V}$ lub silnika elektrycznego. Silnik elektryczny zlokalizowany jest $\mathrm{w}$ jednym przednim kole $\mathrm{w}$ formie piasty (SE). W czasie braku generacji fotoprądu energia wymagana do napędu silnika przekazywana jest $\mathrm{z}$ akumulatorów. 
Jako awaryjne źródło napędu pojazdu zastosowano napęd mechaniczny zasilany mięśniami kierowcy. Napęd przekazywany jest za pomocą pedałów rowerowych podłączonych do koła zębatego. Następnie realizacja napędu za pomocą łańcucha rowerowego przekazywana jest na przekładnie zębatą oraz ostatecznie na jedno tylne koło.

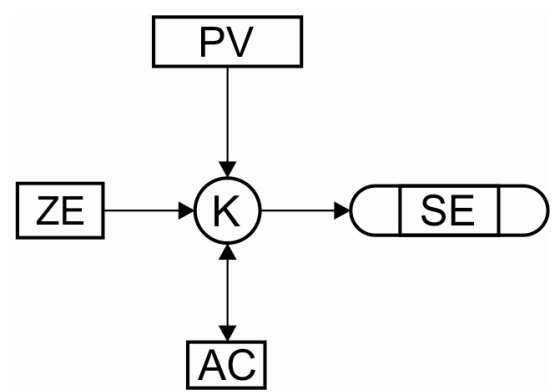

Rys. 3. Model pojazdu solarno-hybrydowego OZI

Fig. 3. Model of solar hybrid vehicle OZI

\subsection{Obliczenia i dobór podzespołów}

W celu doboru odpowiedniego systemu napędowego obliczono minimalną niezbędną moc potrzebną do swobodnego przemieszczania się pojazdu.

Założono, że pojazd poruszał będzie się ze średnią prędkością $20 \mathrm{~km} / \mathrm{h}$, dlatego na podstawie wzoru nr 1 [3][7] obliczono opory toczenia których wartość wyniosła 25,55 [N].

$$
F_{t o}=M \cdot g \cdot F_{t}\left(1+A \cdot v^{2}\right)
$$

gdzie: $\mathrm{F}_{\text {to }}-$ opory toczenia $[\mathrm{N}]$,

$M$ - masa pojazdu $[\mathrm{kg}]$,

$g$ - przyśpieszenie ziemskie,

$\mathrm{F}_{\mathrm{t}}$ - współczynnik tarcia,

$A$ - współczynnik toczenia dla powierzchni asfaltowej

$V^{2}$ - prędkość pojazdu $[\mathrm{km} / \mathrm{h}]$.

Następnie na podstawie wzoru nr 2 [3][7]obliczono opory powietrza. Na potrzeby obliczeniowo założono, że pojazd stanowi pełna bryła, co można potraktować jako przeszacowanie. Obliczeniowy całkowity opór powietrza wyniósł 25,78 [N] przy współczynniku powierzchni czołowej $\mathrm{A}_{\mathrm{t}}$ równym 2,025 $\left[\mathrm{m}^{2}\right][5]$. 


$$
F_{p o}=0,5 \cdot \rho_{p o} \cdot C_{x} \cdot A_{t} \cdot v^{2}
$$

gdzie: $\mathrm{F}_{\mathrm{po}}-$ opory powietrza [N],

$\rho_{\mathrm{po}}-$ gęstość powietrza $[\mathrm{kg} / \mathrm{l}]$ (warunki normalne),

$C_{x}$ - współczynnik oporu aerodynamicznego,

$A_{t}$ - współczynniku powierzchni czołowej [m²],

$V^{2}$ - prędkość pojazdu $[\mathrm{km} / \mathrm{h}]$.

Zgodnie z powyższym szacowana, niezbędna moc przekazywana na koło napędowe wyniosła 293,04 [W], co policzono za pomocą wzoru nr 3 [3][7].

$$
P_{K}=\left(F_{t o}+F_{p o}\right) \cdot V
$$

gdzie: $\mathrm{P}_{\mathrm{k}}-$ moc przekazywana na koło $[\mathrm{W}]$,

$V$ - prędkość pojazdu $[\mathrm{km} / \mathrm{h}]$.

Przy założonej sprawności silnika elektrycznego na poziomie $70 \%$ oszacowano jego minimalną moc na $418,63 \mathrm{~W}$ na podstawie wzoru $\mathrm{nr} 4$. Po analizie rynku wybrano silnik prądu stałego $48 \mathrm{~V}$ o mocy $550 \mathrm{~W}$.

$$
P s=\frac{P_{k}}{\eta_{s}}
$$

gdzie: $\mathrm{P}_{\mathrm{s}}-$ moc silnika [W],

$\eta_{s}-$ sprawność silnika.

Zakładając, że pojazd pracował będzie w większości czasu na maksymalnej mocy 550W oraz czas ciągłej pracy wyniesie 30 minut obliczono, że prąd pobierany przez silnik wyniesie $\mathrm{I}=11,46 \mathrm{~A}$. Uwzględniając częste postoje oraz starty pojazdu podczas których chwilowa moc silnika wynosi 900W oszacowano prąd pobierany na poziomie $15,1 \mathrm{~A}$. Dla założonych parametrów obliczono wymaganą pojemność akumulatorów na poziomie $15,1 \mathrm{Ah}$. Obliczono, że przy wykorzystaniu 4 akumulatorów o pojemności 17Ah i napięciu $12 \mathrm{~V}$ połączonych równolegle oraz silnika o mocy $550 \mathrm{~W}$ czas ciągłej pracy powinien wynieść około 88 minut.

W celu poprawnego i skutecznego działania sytemu zastosowano kontroler ładowania akumulatorów dostosowany do w/w parametrów sytemu, posiadający wbudowany algorytm MPPT. 


\subsection{Badania nad pojazdem}

Badany pojazd nie posiada homologacji dlatego nie może poruszać się $\mathrm{w}$ ruchu ulicznym. $\mathrm{Z}$ tej przyczyny testy przeprowadzono stacjonarnie $\mathrm{z}$ wykorzystaniem rolki rowerowej bez obciążenia. Badania przeprowadzono w zmiennych warunkach nasłonecznienia w dniu 18.04.2014. Celem badań było wyznaczenie maksymalnego czasu pracy przy braku produkcji fotoprądu (z akumulatorami w pełni naładowanymi) oraz z ciągłym udziałem prądu z paneli fotowoltaicznych. Drugim celem badania było oszacowanie rzeczywistego zużycia prądu elektrycznego na potrzeby przemieszczania się HEV ze stałą prędkością.

$\mathrm{Z}$ użyciem czterech multimetrów elektronicznych zbadano wartości napięcia oraz natężenia prądu przepływającego między akumulatorami a kontrolerem ładowania oraz między kontrolerem ładowania a odbiornikiem (w tym przypadku układem napędowym). Podłączenie elementów pomiarowych zobrazowano na ilustracji $\mathrm{nr}$ 4. Symbolem (A) zaprezentowano amperomierz natomiast symbol (V) obrazuje Woltomierz. Wartości prądu mierzone za pomocą w/w urządzeń rejestrowano $\mathrm{w}$ interwale 15 sekundowym. Ilustracja $\mathrm{nr} 5$ przedstawia moc przekazywaną pomiędzy akumulatorami a kontrolerem ładowania oraz między kontrolerem ładowania a układem napędowym bez wykorzystania fotoprądu. Te same parametry z wykorzystaniem fotoprądu zobrazowano na ilustracji nr 6.

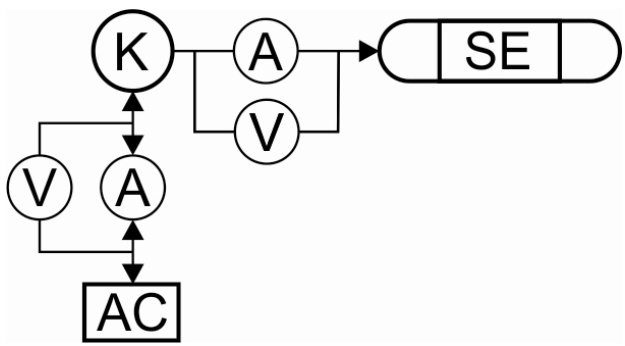

Rys. 4. Schemat podłączeń urządzeń pomiarowych

Fig. 4. Connection diagram of the measuring equipment

Efektywny (bez spadku mocy pozwalającej na poruszanie się pojazdu) pomierzony czas pracy pojazdu bez użycia systemu fotowoltaicznego wyniósł około 2 godzin. Badanie zakończone zostało w punkcie w którym pojazd nie był w stanie poruszać się „samodzielnie”. Wykorzystanie systemu PV miało znaczący wpływ na czas pracy pojazdu. Badanie zostało zakończone po upływie 120 minut, jednak po tym czasie pojazd nadal był w stanie pracować „samodzielnie".

Zauważono również, że system sterowania przepływem energii (K) charakteryzuje się sprawnością około $74 \%$ o czym świadczy strata średnio $26 \%$ prądu przepływającego między akumulatorami a odbiornikiem. 
Przy pracy zasilanej z samych akumulatorów pojazd nie był w stanie uzyskać maksymalnej prędkości $35 \mathrm{~km} / \mathrm{h}$. Podczas wykorzystania energii promieniowania słonecznego pojazd przez cały okres testów utrzymywał maksymalną prędkość $35 \mathrm{~km} / \mathrm{h}$.

Na podstawie rysunku nr 6 zaobserwowano, że w trakcie pracy pojazdu energia elektryczna na bieżąco uzupelniana jest energią pochodzącą z systemu PV. Wraz ze wzrostem energii promieniowania słonecznego maleje udział prądu zmagazynowanego $\mathrm{w}$ akumulatorach do napędzania pojazdu.

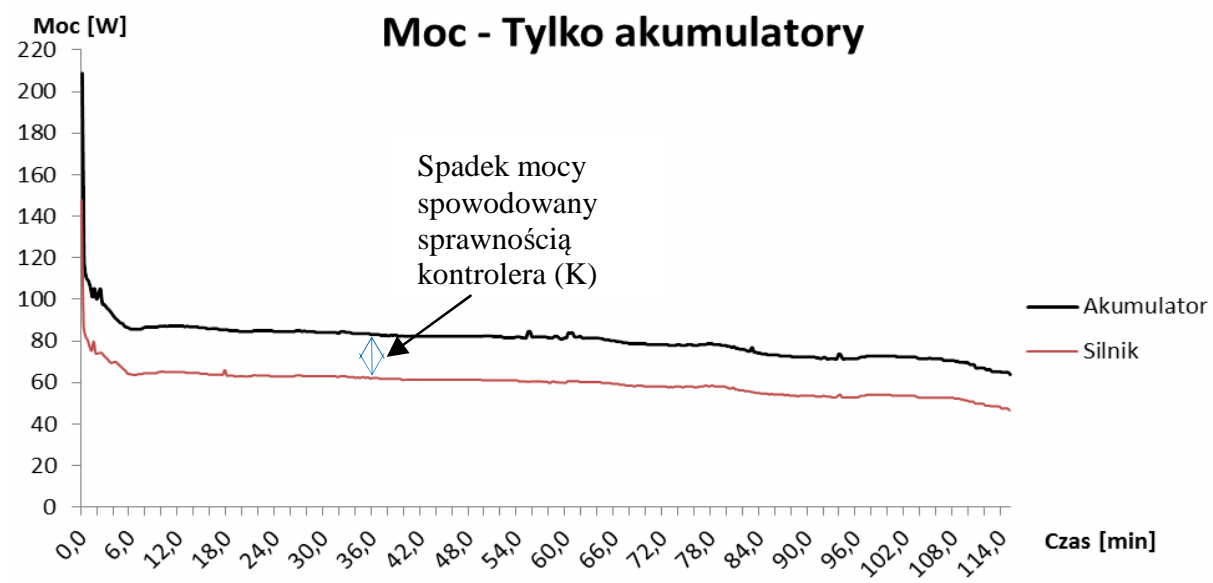

Rys. 5. Charakterystyka mocy prądu elektrycznego pomiędzy AC - K oraz K - SE, bez udziału PV

Fig. 5. The power curve of electric current between AC - K and K - E, without the participation of PV

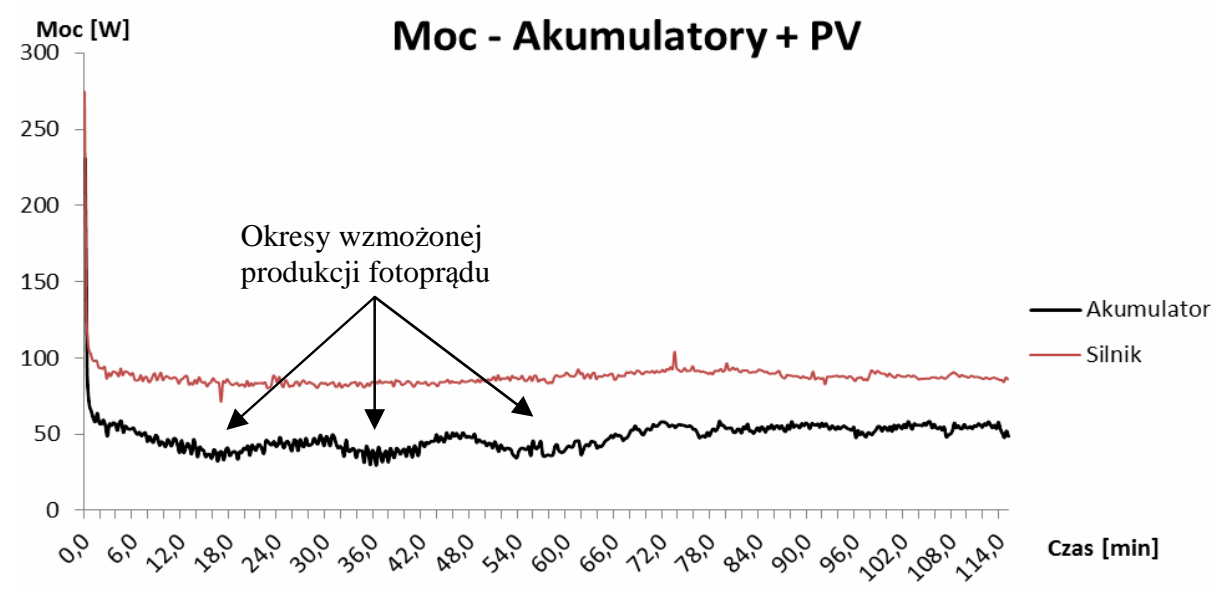

Rys. 6. Charakterystyka mocy prądu elektrycznego pomiędzy AC - K oraz K - SE, z udziałem PV

Fig. 6. The power curve of electric current between $\mathrm{AC}-\mathrm{K}$ and $\mathrm{K}-\mathrm{E}$, with the participation of $\mathrm{PV}$ 


\section{Wnioski}

Na podstawie przeprowadzonych badań można stwierdzić, że systemy fotowoltaiczne $\mathrm{w}$ transporcie drogowym mogą znaleźć zastosowanie przy projektowaniu pojazdów hybrydowych. W szczególności w przypadkach o których mowa w punkcie 1, czyli średni czas przejazdu oraz pokonywane odległości własnym środkiem transportu w aglomeracjach miejskich. Nie można zapominać również o rozsądnym zarządzaniu energią elektryczną w trakcie poruszania się oraz postoju (możliwość zmiany konta nachylenia paneli w stosunku do źródła promieniowania w celu skutecznego ładowania akumulatorów) [4].

Zgodnie z częścią obliczeniową projektu pojazd powinien poruszać się ze stałą prędkością i ze stałym obciążeniem prze około 88 minut. Obliczono również, że moc przekazywana na koło powinna wynieść $293 \mathrm{~W}$ z uwzględnieniem oporów powietrza. Pojazd testowany był stacjonarnie (z wykorzystaniem rolki) dlatego można przyjąć, że moc potrzebna wynosi około połowę tj. 146W. Po uwzględnieniu sprawności silnika okazało się że moc pobierana przez silnik wyniesie $190 \mathrm{~W}$.

Testy wykazały, że pojazd pracował przez ponad 2 godziny a moc pobierana przez silnik średnio wyniosła $88 \mathrm{~W}$. Należy jednak zauważyć, że masa pojazdu podczas testów nie uwzględniała pasażera co znacznie zmniejszyło opory toczenia a tym samym wydłużyło czas pracy. Dlatego można stwierdzić że różnice pomiędzy obliczeniami a pomiarem okazały się znacząco rozbieżne.

Należy zwrócić również uwagę na sprawność stosowanych podzespołów budujących HEV. Stosowanie urządzeń o większej sprawności generować może większy koszt produkcji, co z kolei wpływa negatywnie na opłacalność stosowania systemów fotowoltaicznych. Z całą pewnością rozwój technologii w przyszłości pozwoli na bardziej powszechne wykorzystanie PV w pojazdach hybrydowych.

\section{Literatura}

[1] Arsie I., Rizzo G., Sorrentino M.: Optimal design and dynamic simulation of a hybrid solar vehicle, Department of Mechanical Engineering, University of Salerno, 2006.

[2] Arsie I., Di Martino R., Rizzo G, Sorrentino M.: Toward a supervisory control of a hybrid solar vehicle, Department of Mechanical Engineering, University of Salerno, 2007.

[3] Daniels W. M., Kumar P. R.: Racing with the sun: The optimal use of the solar power automobile, 1997.

[4] Jastrzębska G.: Odnawialne źródła energii i pojazdy proekologiczne, Wydawnictwa Naukowo-Techniczne, Warszawa 2009.

[5] Ozawa H., Nishikawa S., Higashida D.:Development of aerodynamics for a solar race car, JSAE Review 19, s. 343-349, 1998. 
[6] Rizzo G., Arsie I., Sorrentino M.: Solar energy for cars: perspectives, opportunities and problems, Department of Mechanical Engineering, University of Salerno, 2010.

[7] Transport Statistics Great Britain: www.gov.uk/government/collections/transportstatistics-great-britain, 2007.

\section{HYBRID VEHICLES AND PHOTOVOLTAIC SYSTEMS - POSSIBILITY OF USE (PROJECT OZI)}

\section{S u m m a r y}

The paper presents the subject of hybrid vehicles with photovoltaic systems as one of the sources of energy required to operate the system. Describes the basic solutions used in vehicles and describes principle of the each component. The main topic is the design of a hybrid vehicle (OZI) which was made by the students of the Academy of Science and Technology in Krakow. Presents the methodology used in the calculation for vehicle components. The article describes the calculation of rolling resistance, air resistance, and the engine power required to overcome these resistances. Authors matched batteries with the necessary capacity and photovoltaic panels with adequate power. The text describes the most often used constructional solutions for solar hybrid vehicle, but it also shows solutions used in OZI project. Text describes studies that have been conducted over OZI vehicle. The tests describes power flow of an electric current flowing between the battery and charging controller, charger controller and the motor. Studies were carried out without the generation of photocurrent, and with the photocurrent produced by the photovoltaic effect. Authors used electronic multimeters for studies the power flow with 15 seconds reading interval. Additionally the maximum time of continuous operation of the vehicle has been determined. In order to estimate the practical benefits and an indication of the target group of users authors relied on the report of the organization Transport Statistics Great Britain in 2007.

Keywords: Solar energy, rolling resistance, air resistance, transport

Przestano do redakcji: 17.12.2014 $r$.

Przyjęto do druku: 22.06.2015 r.

DOI:10.7862/rb.2015.50 